\title{
The aging of Europe. The unexplored potential
}

Mihajlo Jakovljevic ${ }^{1}$

${ }^{1}$ Health Economics and Pharmacoeconomics, Faculty of Medical Sciences University of Kragujevac, Serbia

\section{ORIGINS OF POPULATION AGING}

Most of the written demographic history of diverse European nations that once inhabited the continent or those that still strive, was the story of young societies whose major, long term survival challenges were poverty, hunger and infectious diseases. Since the early roots of industrial revolution, in some European nations almost two centuries ago, unique new demographic transition began to reveal its face [1]. This long term evolution was encircled with decreasing female fertility, improved early childhood survival, falling mortality rates and extended longevity [2]. The term population aging became broadly recognized description of this phenomenon [3]. Converging causes of such outcome were build-up of welfare states, sexual revolution with inclusion of females into the labor markets and promising deliverables of medical technologies, mostly during the XX century.

\section{THE CASE OF EUROPE}

A myriad of modern day European nations are coping with the growing proportion of elderly citizens with Russia [4], Italy [5], Nordic [6], Balkan [7] nations among some notable examples. These changes have brought several important burden in different areas of social life [8]. The first and most concerning one is the fact that most domestic-driven European labor forces are gradually shrinking [9]. This is partially being compensated by replacement with foreign born skilled migrants [10] but only to some extent [11]. Long term and continuing shortages of labor are particularly visible in some areas such as professional medical and nursing staff in some large countries like Germany [12]. Furthermore, in Europe [13] are consecutively adopted extended work life policies which so far do not tackle gender vulnerabilities in an appropriate scale [14].

\section{CONSEQUENCES FOR MEDICAL CARE ESTABLISHMENTS}

In the medical services arena, growing proportion of elderly citizens is opening few other issues. Most obvious one are higher medical needs of the people in their 70s and 80s [15]. This frequently accumulates to the fact that last years of life ending in an incurable illness demanding expensive intensive care unit admission, palliative or home care, costs more than the entire medical consumption of an individual over his/her life span [16]. Other less striking challenges refer to the difficulties in access to the medical care imposed to the elderly and concerning life quality in this age group. And last but not the least, poor health outcomes among the old patients, frequently interpreted as failures of evidencebased treatments actually present compliance difficulties [17]. Some of these inefficiencies were successfully improved by patient-centered therapy approach which is becoming increasingly adopted throughout the world in recent years [18].

Contemporary health systems have deployed a variety of mechanisms to protect senior citizens from such vulnerabilities. Many legislations tackled equity issues in terms of both access [19] and affordability of medical services [20]. These goals even in wealthiest among European societies were partially accomplished by means of extended insurance coverage [21], provision of community support [22], spreading the network of nursing staff offering home care services [23] and higher reimbursement of medicines [24] in this age group. Generic replacement of brand name drugs proved to be effective tool substantially decreasing the outpatient costs and affordability of pharmaceuticals to the elderly [25]. Among the most promising investments are current European Commission-Japan Horizon 2020 calls for funding of robotic technology research tailored for the home assistance to the elderly and disabled persons [26]. Other less demanding areas
Corresponding author Mihajlo Jakovljevic sidartagothama@gmail.com

Disclosure

The author has no conflicts of interest to declare. 
offering room for significant advances are healthy aging policies [27] involving dietary habits, exercise [28] and coping with mental illnesses most prominent in last decades of life [29].

Certainly one of the cardinal difficulties arising from such a demanding and broad policies refer to the skyrocketing costs of care for senior citizens [30]. These expenditures virtually cross the red lines of both affordability and willingness to pay in many European nations [31]. Diverse strategies were adopted to lessen this burden. Some of the simplest ones were splitting the costs incurred among federal, regional and municipal level budgeting. In harsher social environments, particularly throughout the broad Eastern Europe and Balkans region, large part of these costs were simply moved away from governmental and public responsibility towards the ordinary citizens and their families [32]. This led to the well-known rise in out-of-pocket expenses in these regions [33]. There were two serious adverse effects of the inability of state-owned public insurance funds to provide extensive health coverage for the elderly. First was occurrence of catastrophic household expenditure leading entire families beneath the poverty line due to serious illness of an individual [34]. Another even more important at the national level, was boomerang effect of declining comprehensive preventive, screening and primary outpatient care to the old patients. They were returning back in more severe stages of their illness requiring hospital admission and an expensive and demanding inpatient care. This was probably the most obvious case with core prosperity diseases such as diabetes [35], COPD [36], addiction disorders [37], risky pregnancies [38], community-acquired pneumonia [39], depression [40] and of course, cancer [41]. Back among the mature free market EU-15 economies, all these challenges were present in similar pattern. Traditional high-income economies had stronger historical legacy of preventive medicine, better coverage of rural regions by the network of primary medi- cal care facilities and higher living standards [42]. These advantages are still placing Western European retired citizens in a significantly better position compared to their Central and Eastern European counterparts.

\section{HARVESTING THE UNEXPLORED POTENTIAL OF MATURITY}

Regardless of all aforementioned setback of such a huge demographic change, we should be aware that "grey transition"does not inevitably imposes only weakness to the contemporary communities in Europe and beyond. Many countries successfully implemented extensions of mandatory and voluntary retirement age limits upwards in both males and females [43]. Some professions actually benefited from these gradual legislative changes because of lower costs of new staff recruitment and training [44]. In a post-industrial society, benefiting from expanding ICT technologies, distant work from home proved to be surprisingly convenient. It actually allowed older workers with transport limitations and chronic illnesses to contribute with their huge experience and knowledge further on, instead of being forcibly retired by law [45]. This case is typical in a large scale of scientific, artistic, advertising or public administration related duties [46]. Furthermore, many senior positions in a variety of businesses, governmental and municipal affairs, industrial and service provision sectors of the economy demand effective leadership capacity [47]. This ability for evidence-based decision making was proven in managerial sciences to be more dependent on overall life experience and wisdom than to the precise technical skills mostly mastered by younger people [48]. These and many other possible benefits of the growing proportion of senior citizens should not be omitted in foreseeable future. European Union's and Commonwealth of Independent States' authorities will probably remain the most capable institutional framework delivering long term strategies to cope with population aging in both the West and East of the European region.

\section{REFERENCES}

1. Bourdelais P. The aging of the population of france (1789-1989). Histoire 1989: 128: 18-26

2. Jakovljevic M, Vukovic M, Fontanesi J, Life Expectancy and Health Expenditure Evolution in Eastern Europe DiD and DEA analysis. Expert Rev Pharmacoecon Outcomes Res 2015 [Epub ahead of print]; http://dx.doi.org/1 $0.1586 / 14737167.2016 .1125293$

3. Bostrom, J.Aging baby boomers will drive health-care innovation. Aging 1908; 10: 23

4. Mazzola P, Rimoldi SM, Rossi P, et al. Aging in Italy: The Need for New Welfare Strategies in an Old Country. Gerontologist 2015; 9: pii: gnv152; http://dx.doi.org/10.1093/geront/gnv152 
5. Matytsin M, Moorty L M, Richter, K. From demographic dividend to demographic burden ? regional trends of population aging in Russia. Policy Research working paper; no. WPS 7501. Washington, D.C.: World Bank Group, 2015. Available at: http://documents.worldbank.org/curated/en/2015/11/25485357/demographic-dividend-demographic-burden-regional-trends-population-aging-russia (last accessed December 2015)

6. Hörnström, L, Perjo L, Johnsen IHG, et al. Nordic ways of dealing with depopulation and ageing in rural and peripheral areas. Nordregio Policy Brief 2015: 8. Available at: http://www.nordregio.se/en/Publications/Publications-2015/Nordic-ways-of-dealing-with-depopulation-and-ageing--in-rural-and-peripheral-areas/ (last accessed December 2015)

7. Jakovljevic M, Laaser U. Population aging from 1950 to 2010 in seventeen transitional countries in the wider region of South Eastern Europe. SEEJPH 2015; http://dx.doi.org/10.12908/SEEJPH-2014-42

8. Heikkinen E. Health implications of population aging in Europe. World Health Stat Q 1987; 40: 22-40

9. Schulz JH. Aging and the labor force: issues in contemporary retirement. Science 1988; 241: 1516-7; http://dx.doi. org/10.1126/science.241.4872.1516

10. Immigration and aging in the Belgian regions. IWEPS, 2004. http://www.iweps.be/sites/default/files/dp0402_0. pdf

11. Chiswick BR. High Skilled Immigration in the International Arena (September 2005). IZA Discussion Paper No. 1782. Available at SSRN: http://ssrn.com/abstract=826389 (last accessed December 2015)

12. Kuhlmann E, Larsen C. Why we need multi-level health workforce governance: Case studies from nursing and medicine in Germany. Health Policy 2015; pii: S0168-8510(15)00191-8; http://dx.doi.org/10.1016/j.healthpol.2015.08.004

13. ISCH COST Action IS1211 Cancer and Work Network (CANWON). Available at: https://www.amc.nl/web/AMCwebsite/CANWON/Project-overview.htm (last accessed December 2015)

14. ISCH COST Action IS1409 Gender and health impacts of policies extending working life in western countries. Available at: http://www.cost.eu/COST_Actions/isch/IS1409 (last accessed December 2015)

15. Getzen TE. Population aging and the growth of health expenditures. J Gerontol 1992; 47: S98-104; http://dx.doi. org/10.1093/geronj/47.3.S98

16. Kovacević A, Dragojević-Simić V, Rancić N, et al. End-of-life costs of medical care for advanced stage cancer patients. Vojnosanit Pregl 2015; 72: 334-41; http://dx.doi.org/10.2298/VSP1504334K

17. Savic D, Jakovljevic M. Estimate of clinical outcomes from the patient perspective is important for clinical decision making. Rational treatment 2012; 4: 47-9

18. Boyd CM, Darer J, Boult C, et al. Clinical practice guidelines and quality of care for older patients with multiple comorbid diseases: implications for pay for performance. JAMA 2005; 294: 716-24; http://dx.doi.org/10.1001/ jama.294.6.716

19. Judy WW, Solomon CK, George O. Understanding the Context of Healthcare Access among the Elderly in Informal Settlement Kibera, Nairobi, Kenya. International Journal of Health Sciences and Research 2015; 5: 259-69.

20. Jakovljevic M, Groot W, Souliotis K. Health care financing and affordability in the emerging global markets. Frontiers in Public Health 2015 [Epub ahead of print]

21. Bonsang E, Schoenmaeckers J. (2015). Long-term care insurance and the family: does the availability of potential caregivers substitute for long-term care insurance? In: Ageing in Europe - Supporting Policies for an Inclusive Society. De Gruyter, 2015: pp. 369-80; http://dx.doi.org/10.1515/9783110444414

22. Kobayashi T, Suzuki E, Noguchi M, et al. Community-Level Social Capital and Psychological Distress among the Elderly in Japan: A Population-Based Study. PLoS One 2015; 10: e0142629; http://dx.doi.org/10.1371/journal. pone.0142629

23. Fontaine R, Pino M, Jean-Baptiste M, et al. Older adults living with cognitive and mobility-related limitations: social deprivation and forms of care received. In: Ageing in Europe - Supporting Policies for an Inclusive Society. De Gruyter, 2015: 103-13; http://dx.doi.org/10.1515/9783110444414-011

24. Petrusic T, Jakovljevic M, Budget impact of publicly reimbursed prescription medicines in The Republic of Srpska. Front Public Health 2015; 3: 213; http://dx.doi.org/10.3389/fpubh.2015.00213

25. Jakovljevic MB, Nakazono S, Ogura S. Contemporary generic market in Japan-key conditions to successful evolution. Expert Rev Pharmacoecon Outcomes Res 2014; 14: 181-94; http://dx.doi.org/10.1586/14737167.2014.88 1254

26. European Commission. EU-Japan cooperation on Novel ICT Robotics based solutions for active and healthy ageing at home or in care facilities. Available at: https://ec.europa.eu/research/participants/portal/desktop/en/opportunities/h2020/topics/2433-sc1-pm-14-2016.html (last accessed December 2015)

27. Netz Y, Wu MJ, Becker BJ, et al. Physical activity and psychological well-being in advanced age: a meta-analysis of intervention studies. Psychol Aging 2005; 20: 272-84; http://dx.doi.org/10.1037/0882-7974.20.2.272

28. Netz Y, Jacob T. Exercise and the psychological state of institutionalized elderly: a review. Percept Mot Skills 1994; 79: 1107-18; http://dx.doi.org/10.2466/pms.1994.79.3.1107

29. Takeda F, Noguchi H, Monma T, et al. How Possibly Do Leisure and Social Activities Impact Mental Health of Middle-Aged Adults in Japan?: An Evidence from a National Longitudinal Survey. PLoS One 2015; 10: e0139777; http://dx.doi.org/10.1371/journal.pone.0139777 
30. Ogura, S. The cost of aging: Public finance perspectives for Japan. In Aging in the United States and Japan: Economic Trends. Chicago: University of Chicago Press, 1994; pp. 139-174

31. Cuaresma JC, Loichinger E, Vincelette GA. Aging and income convergence in Europe: A survey of the literature and insights from a demographic projection exercise. Economic Systems 2015 [Epub ahead of print]; http://dx.doi. org/10.1016/j.ecosys.2015.07.003

32. Jakovljevic MB, Health Expenditure Dynamics in Serbia 1995-2012. Hospital Pharmacology 2014; 1: 180-3

33. Jakovljevic M, Comparison of Historical Medical Spending Patterns among the BRICS and G7. J Med Econ 2015: 1-7 [Epub ahead of print]; http://dx.doi.org/10.3111/13696998.2015.1093493

34. Moser K, Pavlova M, Groot W. The financial burden of out-of-pocket patient payments in the European Union and accession countries: Results of a systematic literature review. Zdrowie Publiczne i Zarządzanie 2015; $12: 239247$

35. Biorac N, Jakovljević M, Stefanović D, et al. Assessment of diabetes mellitus type 2 treatment costs in the Republic of Serbia. Vojnosanit Pregl 2009; 66: 271-6; http://dx.doi.org/10.2298/VSP0904271B

36. Lazic Z, Gajovic O, Tanaskovic I, et al. GOLD stage impact on COPD direct medical costs in elderly. Health Behav \& Pub Health 2012; 2: 1-7

37. Jakovljevic M, Jovanovic M, Rancic N, et al. LAT Software Induced Savings on Medical Costs of Alcohol Addicts' Care - Results from a Matched-Pairs Case-Control Study. PLoS One 2014; 9: e111931; http://dx.doi.org/10.1371/ journal.pone.0111931

38. Jakovljevic M, Varjacic M, Jankovic SM. Cost-Effectiveness of Ritodrine and Fenoterol for Treatment of Preterm Labor in a Low-Middle-Income Country: A Case Study. Value Health 2008; 11: 149-53; http://dx.doi.org/10.1111/ j.1524-4733.2007.00222.x

39. Cupurdija V, Lazic Z, Petrovic M, et al. Community-acquired pneumonia: economics of inpatient medical care vis-à-vis clinical severity. J Bras Pneumol 2015; 41: 48-57; http://dx.doi.org/10.1590/S1806-37132015000100007

40. Jakovljević MB, Tetsuji Y, Ching CC, et al. Cost-Effectiveness of Depressive Episode Pharmacological Treatment. Hospital Pharmacology 2015; 2: 235-245

41. Jakovljevic M, Folic M, Dagovic A, et al. Hospital oncology costs among the cohort of elderly in an aging SouthEastern European nation. Farmeconomia. Health economics and therapeutic pathways 2015; 16: 3-5; http:// dx.doi.org/10.7175/fe.v16i1.1167

42. Carlson, P. Self-perceived health in East and West Europe: another European health divide. Soc Sci Med 1998; 46: 1355-66; http://dx.doi.org/10.1016/S0277-9536(97)10093-4

43. Hairault JO, Sopraseuth T, Langot F. Distance to retirement and older workers 'employment: The case for delaying the retirement age. Journal of the European Economic association 2010; 8: 1034-76; http://dx.doi. org/10.1111/j.1542-4774.2010.tb00547.x

44. Vaupel JW, Loichinger E. Redistributing work in aging Europe. Science 2006; 312: 1911-3; http://dx.doi. org/10.1126/science. 1127487

45. Johnson RW, Neumark D. Age discrimination, job separation, and employment status of older workers: Evidence from self-reports. National Bureau of Economic Research NBER Working Paper 5619, 1996; http://dx.doi. org/10.3386/w5619

46. Austin C, Des Camp E, Flux D, et al. Community development with older adults in their neighborhoods: The elder friendly communities program. Families in Society: The Journal of Contemporary Social Services 2005; 86: 4019; http://dx.doi.org/10.1606/1044-3894.3438

47. Kloseck M, Crilly RG, Mannell RC. Involving the community elderly in the planning and provision of health services: predictors of volunteerism and leadership. Can J Aging 2006; 25: 77-91; http://dx.doi.org/10.1353/ cja. 2006.0025

48. Gutmann, D. Age and leadership: cross cultural observations. Aging and political leadership 1982; 2: 109-120; http://dx.doi.org/10.1080/07351698209533438 